\title{
Pembuatan Obat Kumur Alami Daun Sirih Bagi Anggota Aisyiyah di PRA Cabang Perumnas I dan Jakasampurna
}

\author{
Hanifah Rahmi ${ }^{1 *}$, Rizky Arcinthya Rachmania ${ }^{1}$, Elly Wardani ${ }^{1}$ \\ ${ }^{1}$ Fakultas Farmasi dan Sains, Universitas Muhammadiyah Prof. DR. Hamka, Klender, Jakarta Timur, \\ Indonesia 13460 \\ Email: hanifah rahmi@uhamka.ac.id
}

\begin{abstract}
Abstrak
Daun sirih merupakan tanaman obat tradisional yang erat kaitannya dengan kesehatan gigi dan mulut. Daun sirih diketahui sebagai salah satu Bahan alami yang memiliki kemampuan sebagai obat kumur karena aktivitasnya sebagai antibakteri penyebab plak gigi. Meskipun telah banyak diketahui khasiatnya, pemanfaatan dan pembuatan daun sirih sebagai obat kumur bagi masyarakat perlu disosialisasikan untuk menjaga kesehatan mulut. Pengabdian masyarakat ini dilaksanakan dengan tujuan untuk meningkatkan pengetahuan mengenai pencegahan bau mulut dengan obat kumur alami dan cara pembuatannya dengan sederhana kepada masyarakat sehingga dapat meningkatkan derajat kesehatannya secara mandiri serta meningkatkan pendapatan ekonomi. Mitra yang dipilih menjadi lokasi pengabdian masyarakat didasarkan pada pertimbangan berdasarkan kepatutan sumber data dan informasi yang dikumpulkan melalui kunjungan serta diskusi. Target yang dicapai adalah ibu-ibu rumah tangga yang tergolong masyarakat ekonomi menengah ke bawah. Profil masyarakat di sebagian warga ini tepat untuk mendapatkan tambahan pengetahuan dan keterampilan yang berguna untuk peningkatan kualitas hidup. Pengabdian masyarakat ini dibagi menjadi 2 hari, hari pertama berupa pemaparan materi dan hari kedua berupa pelatihan pembuatan obat kumur. Hasil yang diperoleh yaitu formula obat kumur yang sesuai dengan evaluasi rasa, warna, dan bau dari orientasi formula. Formula yang terpilih yaitu menggunakan daun sirih dan daun mint (1:1). Dari pelatihan ini diharapkan anggota Aisyiyah Cabang Perumnas I sebagai stake holder dapat menyebarkan informasi resep pembuatan obat kumur yang sederhana dan harga terjangkau kepada anggota masyarakat lainnya.
\end{abstract}

Kata kunci: Obat Kumur, Daun Sirih, Aisyiyah

\section{Abstract}

Betel leaf is a traditional medicinal plant that is closely related to dental and oral health. Betel leaf is known as one of the natural ingredients that has the ability as a mouthwash because its activity as an antibacterial cause of dental plaque. Although it has been widely known, the use and produce of betel leaf as a mouthwash for the community needs to be socialized to maintain oral health. Community service is carried out with the aim of increasing knowledge about prevention of bad breath with natural mouthwash and simple methods of making it to the community so that they can improve their health status independently and increase economic income. The partner chosen as the location for community service is based on consideration based on the propriety of sources of data and information collected through visits and discussions. The target achieved is housewives belonging to the middle to lower economic community. The profile of the community in some residents is right to get additional knowledge and skills that are useful for improving quality of life. Community service is divided into 2 days, the first day in the form of material presentation and the second day in the form of training on making mouthwash. The results obtained were the mouthwash formula that was in accordance with the evaluation of taste, color, and odor from the orientation of the formula. The selected formula is using betel leaves and mint leaves (1:1). From this training, it is expected that members of Aisyiyah of Perumnas I Branch, as stake holders, can disseminate information on simple and affordable prices for making mouthwash to other community members.

Keywords: Mouthwash, Betel leaf, Aisyiyah, 
Format Sitasi: Rahmi H., Rachmania R.A., Wardani E. (2019). Pembuatan Obat Kumur Alami Daun Sirih Bagi Anggota Aisyiyah di PRA Cabang Perumnas I dan Jakasampurna. Jurnal Solma, 08(1): 119126. Doi: http://dx.doi.org/10.29405/solma.v8i1.3102

Diterima: 15 Februari 2019 | Revisi: 04 April 2019 | Dipublikasikan: 30 April 2019.

\section{PENDAHULUAN}

Aisyiyah merupakan salah satu organisasi otonom di Muhammadiyah diharapkan mampu untuk mandiri dalam membangun dan mengembangkan sistem organisasinya. Aisyiyah di Daerah Kota Bekasi memiliki beberapa cabang, diantaranya Cabang Pondok Gede, Cabang Bekasi Utara, Cabang Rawa Lumbu, Cabang Bekasi Selatan, Cabang Mustika Jaya, Cabang Medan Satria, Cabang Bekasi Barat, Cabang Perumnas I, Cabang Bekasi Timur I dan Bekasi Timur II.

Cabang-cabang Aisyiyah di Kota Bekasi memiliki kemandirian ekonomi yang berbeda-beda untuk menjalankan organisasinya, sehingga dikategorikan kuat, sedang, dan lemah. Cabang Pondok Gede, Cabang Bekasi Utara, Cabang Rawa Lumbu dan Cabang Bekasi Selatan dapat dikategorikan memiliki kemandirian yang kuat karena memiliki amal usaha yang mampu menopang kegiatan organisasi. Adapun Cabang Bekasi Barat, Cabang Perumnas I, Cabang Bekasi Timur I dan Bekasi Timur II dikategorikan memiliki kemandirian yang sedang. Sedangkan Cabang Mustika Jaya dan Cabang Medan Satria dikategorikan memiliki kemandirian yang lemah karena selain cabang yang baru terbentuk serta belum memiliki amal usaha yang mendukung kemandirian menjalankan organisasi.

Cabang Aisyiyah yang kami pilih untuk mengadakan pengabdian masyarakat yaitu, Cabang Perumnas I. Cabang ini memiliki amal usaha berupa penjualan air mineral "Suli" yang dapat menambah kas organisasi. Aisyiyah Cabang Perumnas I memiliki lokasi yang tidak jauh dari tempat tinggal pelaksana pengabdian. Salah satu kegiatan yang rutin dilakukan oleh anggota Aisyiyah cabang ini adalah arisan bulanan untuk menjalin silaturahmi antar anggota. Pengabdian ini dilaksanakan bersamaan dengan kegiatan rutin tersebut.

Obat kumur merupakan suatu larutan atau cairan yang digunakan untuk membantu memberikan kesegaran pada rongga mulut serta membersihkan mulut dari plak dan organisme yang menyebabkan penyakit dirongga mulut. Umumnya, sifat antibakteri obat kumur terutama ditentukan oleh bahan aktif yang terkandung di dalamnya (Susilo, Akbar, \& Pratinaningsih, 2018). 
Bahan alami telah banyak diteliti memiliki kemampuan sebagai obat kumur karena aktivitasnya sebagai antibakteri penyebab plak gigi. Salah satu bahan alami yang memiliki aktivitas antibakteri yaitu daun sirih. Daun sirih merupakan tanaman obat tradisional yang erat kaitannya dengan kesehatan gigi dan mulut. Daun sirih berguna untuk menguatkan gigi, menyembuhkan sariawan, menghilangkan bau mulut dan menghentikan perdarahan gusi. Efek astringent bahan ini, telah diketahui sebagai obat kumur, tidak menimbulkan iritasi selaput lendir rongga mulut (Agustin, 2005). Penggunaan sirih sebagai bahan obat mempunyai dasar kuat karena adanya kandungan minyak atsiri yang merupakan komponen fenol alami sehingga berfungsi sebagai antiseptik yang kuat. Sepertiga dari minyak atsiri tersebut terdiri dari fenol dan sebagian besar adalah kavikol. Kavikol inilah yang memiliki daya pembunuh bakteri lima kali lipat dari fenol biasa (Agustin, 2005). Daun sirih yang masih muda mengandung enzim diastase, gula, dan minyak atsiri lebih banyak daripada daun yang tua.

Dalam daun sirih 100 gram terdapat kandungan: air 85,4 mg; protein 3,1 mg; karbohidrat 6,1 mg; serat 2,3 mg; yodium 3,4 mg; mineral 2,3 mg; kalsium $230 \mathrm{mg}$; fosfor $40 \mathrm{mg}$; besi ion 3,5 mg; karoten (vitamin A) $9600 \mathrm{iu}$, kalium nitrat 0,26-0,42 mg; tiamin $70 \mathrm{mg}$; riboflavin $30 \mathrm{mg}$; asam nikotinal 0,7 mg; vitamin C $5 \mathrm{mg}$; kanji 1,0-1,2\%; gula non reduksi $0,6-2,5 \%$; gula reduksi1,4-3,2\%. Sedangkan minyak atsirinya terdiri dari: alilkatekol 2,7-4,6\%; kadinen 6,7-9,1\%; karvakol 2,2-4,8\%; kariofilen 6,2-11,9\%; kavibetol $\quad 0,0-1,2 \%$; kavikol 5,1-8,2\%; sineol 3,6-6,2\%; eugenol 26,8-42,5\%; eugenol metil eter 26,8-15,58\%; pirokatekin. Senyawa kariofilen bersifat antiseptik dan anestetik lokal, sedangkan senyawa eugenol bersifat antiseptik dan analgesik topikal (Dian, 2005).

Pembuatan obat kumur dari ekstrak daun sirih dilakukan dengan metode infundasi. Infundasi adalah ekstraksi dengan cara perebusan, dimana pelarutnya adalah air pada suhu $90^{\circ} \mathrm{C}$ selama 15 menit. Infundasi merupakan proses penyarian yang paling umum digunakan untuk menyari kandungan zat aktif yang larut dalam air dari bahan-bahan nabati. Metode ini mempunyai kelemahan yaitu sari yang dihasilkan tidak stabil dan mudah tercemar oleh kuman dan kapang sehingga sari yang diperoleh dengan cara ini tidak boleh disimpan lebih dari 24 jam (Irwanto, 2009).

Sebagai tanaman yang berkhasiat obat, daun sirih sebaiknya dimanfaatkan dalam keadaan segar, sehingga cara meramunya harus mengikuti cara-cara yang lazim agar khasiat obat yang dikandungnya tidak pudar. Menurut Kloppenburg Versteegh, seorang 
ahli tanaman obat asli Indonesia menganjurkan penggunaan ekstrak daun sirih untuk berkumur jika mulut mengalami pembengkakan, membersihkan napas yang bau akibat pembusukan gigi serta untuk menghentikan darah dan membersihkan luka saat gigi dicabut. Berdasarkan penelitian yang dilakukan oleh Kartini Hasballah, ekstrak daun sirih menunjukkan aktivitas antibakteri yang mampu menghambat pertumbuhan bakteri Streptococcus mutans, Lactobacillus kaesal dan Actinomycete viscosus (Kartini \& Murniana, 2005; Riyanti, Sutyasningsih, \& Sarsongko, 2018)

Mengingat kemanfaatan obat kumur daun sirih, masyarakat perlu mengetahui lebih dalam mengenai manfaat obat kumur ini. Penyampaian pengetahuan yang baik ini kepada masyarakat dapat terlaksana melalui Program Pemberdayaan dan Pengabdian Masyarakat (PPPM) yang dilakukan Fakultas Farmasi dan Sains UHAMKA. Selain penyampaian manfaat obat kumur bagi kesehatan, kegiatan PPPM ini mencakup cara pembuatan obat kumur. Dengan memberikan pengetahuan manfaat obat kumur dan cara pembuatannya kepada masyarakat diharapkan masyarakat terutama ibu-ibu Aisyiyah dapat meningkatkan derajat kesehatannya secara mandiri serta meningkatkan pendapatan ekonomi.

\section{MASALAH}

Pemecahan masalah yang ada di masyarakat berkaitan keberhasilan pembuatan obat kumur dengan berbagai manfaatnya, dapat direalisasikan melalui kegiatan Pemberdayaan dan Pengabdian Masyarakat di Anggota Aisyiyah PCA Perumnas 1, Kelurahan Kayuringin Jaya, Bekasi Selatan ini berupa pembuatan obat kumur alami dan biaya yang relatif terjangkau serta penyuluhan tentang manfaat dan kandungan obat kumur. Dengan adanya pembekalan cara pembuatan obat kumur dalam kegiatan PPPM ini, dapat memberikan keterampilan kepada masyarakat untuk diaplikasikan. Mengingat permasalahan mitra yaitu banyaknya waktu luang yang tidak dipergunakan untuk meningkatkan keterampilan dan pendapatan Anggota Aisyiyah maka solusi yang ditawarkan yaitu memberikan ilmu berupa bagaimana pembuatan obat kumur dari bahan alami. Sehingga dapat meningkatkan ekonomi ataupun pendapatan organisasi atau Anggota Aisyiyah.

\section{METODE PELAKSANAAN}

Orientasi formula perlu dilakukan sebelum memberikan pelatihan pembuatan obat kumur. Selain menggunakan daun sirih, orientasi dilakukan dengan variasi rasa dari bahan alam yang lain, yaitu daun mint, jeruk nipis, jeruk lemon, dan teh hijau. Keempat variasi 
rasa tersebut dicampurkan dengan ekstrak daun sirih dengan perbandingan volume yang sama (1:1). Masing-masing formula dievaluasi warna, rasa, dan baunya.

Setelah melakukan orientasi, formula terbaik dipilih untuk digunakan pada saat pelatihan pembuatan obat kumur. Pelatihan dilakukan selama 2 hari; Hari Pertama, panitia memberikan penyuluhan dan materi tentang manfaat obat kumur serta daun sirih. Sedangkan Hari Kedua, panitia memberikan cara pembuatan daun sirih serta membagikan prototipe obat kumur yang sudah dibuat sehari sebelumnya agar dapat dicoba oleh peserta.

Pembuatan obat kumur dari ekstrak daun sirih dilakukan dengan metode infundasi. Infundasi adalah ekstraksi dengan cara perebusan, dimana pelarutnya adalah air pada suhu $90^{\circ} \mathrm{C}$ selama 15 menit. Infundasi merupakan proses penyarian yang paling umum digunakan untuk menyari kandungan zat aktif yang larut dalam air dari bahan-bahan nabati. Metode ini mempunyai kelemahan yaitu sari yang dihasilkan tidak stabil dan mudah tercemar oleh kuman dan kapang sehingga sari yang diperoleh dengan cara ini tidak boleh disimpan lebih dari 24 jam (Irwanto, 2009). Evaluasi dilakukan dengan pemeriksaan Organoleptik meliputi rasa, bau dan tekstur.

\section{PEMBAHASAN}

Kegiatan pengabdian kepada masyarakat ini bertujuan untuk meningkatan derajat kesehatan masyarakat melalui peningkatan pemahaman/pengetahuan banyaknya manfaat yang dikandung dari daun sirih sebagai salah satu bahan alami yang digunakan untuk obat kumur serta peningkatan ketrampilan PRA Aisyiyah melalui pelatihan pembuatan obat kumur dengan metode sederhana yaitu infundasi dan biaya yang relatif terjangkau. Melalui kegiatan pengabdian kepada masyarakat yang ditujukan kepada anggota PRA Aisyiyah, maka diharapkan dalam lingkup keluarga PRA Aisyiyah dapat meningkatkan derajat kesehatannya melalui pengetahuan tentang kesehatan rongga mulut. Keterampilan dalam cara pembuatan obat kumur ini diharapkan dapat diaplikasikan dalam kegiatan ekonomi Aisyiyah untuk meningkatkan pendapatan rumah tangga.

Obat kumur dapat dibuat dalam berbagai variasi rasa. Pada kegiatan orientasi yang telah kami lakukan di laboratorium Biokimia FFS UHAMKA, formula obat kumur dibuat 4 variasi rasa yaitu, original daun sirih, penambahan jeruk nipis, penambahan jeruk lemon, penambahan teh hijau, dan penambahan daun mint. Hasil orientasi formula diperoleh formula terbaik, yaitu formula obat kumur dengan daun sirih dan daun mint (1:1). Pemilihan formula ini didasarkan pada rasa dan selera.

Kegiatan ini diselenggarakan pada tanggal 16 Desember 2018 dan 10 Februari 2019 
bertepatan dengan kegiatan arisan anggota Aisyiyah. Pelaksanaan tanggal 16 Desember 2018 bertempat di Jl. Palem Raya No. 101 Perumnas I Bekasi dihadiri sebanyak 14 orang ibu-ibu anggota Aisyiyah. Pada pelaksanaan hari pertama ini, panitia pengabdian memberikan materi mengenai pengenalan obat kumur dan manfaat daun sirih kepada ibuibu anggota Aisyiyah. Materi disampaikan oleh Hanifah Rahmi, M.Biomed. dan moderator Rizky Arcinthya Rachmania, M.Si. Meskipun banyak ibu-ibu yang sudah mengenal daun sirih, namun belum banyak yang mengetahui kandungan zat aktif serta berbagai manfaat dari daun sirih.

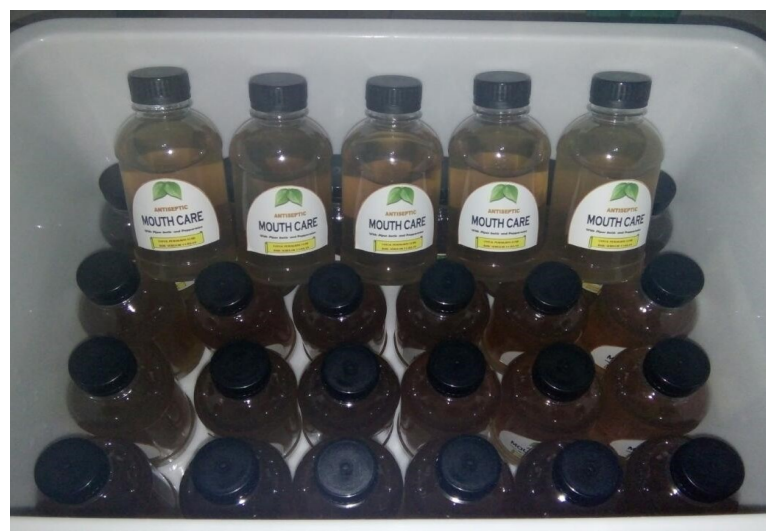

Gambar 1. Obat kumur hasil pelatihan.

Kegiatan pengabdian kedua dilaksanakan pada tanggal 10 Februari 2019 bertempat di Jl. Jeruk 7 No. 183 yang dihadiri sebanyak 14 peserta ibu-ibu anggota Aisyiyah Cabang Perumnas I, Bekasi Selatan. Pada pelaksanaan hari kedua ini, panitia pengabdian memberikan pelatihan mengenai pembuatan obat kumur kepada ibu-ibu anggota Aisyiyah. Materi disampaikan oleh Elly Wardani, M.Farm., Apt. dan moderator oleh Hanifah Rahmi, M.Biomed. Hasil obat kumur yang dibuat memiliki warna yang menarik (Gambar 1) dengan rasa yang tidak terlalu pahit dan bau khas daun sirih dan daun mint yang menyegarkan.

Respon anggota Aisyiyah terhadap kegiatan pertama dan kedua terlihat sangat antusias mengingat obat kumur merupakan cairan pembersih rongga mulut yang penting untuk menjaga kesehatan. Dengan adanya penyuluhan tentang manfaat dan kandungan daun sirih, anggota Aisyiyah dapat mengetahui betapa pentingnya kesehatan rongga mulut terutama menggunakan bahan alam. Tidak hanya digunakan sebagai obat kumur, daun sirih juga memiliki khasiat lain dapat digunakan untuk pengobatan luka bakar ringan, gusi berdarah, inflamasi, serta sebagai produk pembersih kewanitaan karena kandungan minyak atsiri 1-4,2\%, air, protein, lemak, karbohidrat, kalsium, fosfor, vitamin A, B, C yodium, 
guladan pati. Dari berbagai kandungan tersebut, dalam minyakatsiri terdapat fenol alam (senyawa alami) yang mempunyai daya fungisida yang sangat kuat tetapi tidak sporosid (Soemiati \& Elya, 2002).

Metode infundasi yang digunakan dapat menyari zat kandungan aktif dari daun sirih yang larut dalam air. Proses ini dilakukan pada suhu $90-95^{\circ} \mathrm{C}$ selama 15 menit. Hal yang perlu diperhatikan dalam metode ini, antara lain pembuatan obat kumur harus dilakukan sehari sebelum digunakan. Jika ingin bertahan selama tiga hari sebaiknya ditambahkan pengawet alami serta dilakukan penyaringan dengan kertas saring ukuran tertentu agar diperoleh kemurnian yang lebih baik.

\section{KESIMPULAN}

Pada bagian kesimpulan dikemukakan tingkat ketercapaian target kegiatan di lapangan, ketepatan atau kesesuaian antara masalah/persoalan dan kebutuhan/tantangan yang dihadapi, dengan metode yang diterapkan. Selain itu juga dijelaskan dampak dan manfaat kegiatan yang telah dilaksanakan. Bagian ini diakhiri dengan rekomendasi untuk kegiatan PKM berikutnya.

\section{UCAPAN TERIMA KASIH}

Ucapan terima kasih terutama ditujukan kepada LPPM UHAMKA yang telah memberikan bantuan dana pelaksanaan kegiatan pelatihan ini. Terima kasih juga kami sampaikan kepada mitra Cabang Aisyiyah Perumnas I atas kesempatan dan waktu yang diberikan sehingga kegiatan dapat berlangsung dengan lancar.

\section{DAFTAR PUSTAKA}

Agustin, D. (2005). Perbedaan Khasiat Antibakteri Bahan Irigasi antara Hidrogen Peroksida 3\% dan Infusum daun Sirih 20\% terhadap Bakteri mix. Majalah Kedokteran Gigi (Dental Journal), 38(1), 45-47.

Irwanto, I. (2009). Ekstraksi Menggunakan Proses Infundasi, Maserasi dan Perlokasi, Situs Biologi Farmasi dan Kimia.

Kartini, H., \& Murniana, M. (2005). Aktivitas Antibakteri Ekstrak Daun Eclipta alba L. serta Ekstrak dan Minyak Atsiri Daun Piper betle L. terhadap Bakteri Penyebab Karies Gigi. Jurnal Kedokteran YARSI, 13(3).

Riyanti, H. B., Sutyasningsih, S., \& Sarsongko, A. W. (2018). Identifikasi Rhodamin B dalam Lipstik dengan Metode KLT dan Spektrofotometri UV-VIS. Bioeduscience, 2(1), 68-73. https://doi.org/10.29405/j.bes/68-73121338 
Soemiati, A., \& Elya, B. (2002). Uji pendahuluan efekkombinasi anti jamur infus dan sirih (P. betle), kulitbuah delima (Punica granatum L.) dan rimpang kunyit(Curcuma domestica Val.) terhadap jamur Candidaalbicans. Makara, 149-150.

Susilo, S., Akbar, B., \& Pratinaningsih, I. (2018). Pengaruh ekstrak etanol daun sambiloto terhadap jumlah dan motilitas spermatozoa mencit jantan. Jurnal Biodjati, 3(2), 166172. https://doi.org/10.15575/biodjati.v3i2.3505

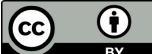

(C) 2019 Oleh authors. Lisensi Jurnal Solma, LPPM-Uhamka, Jakarta. Artikel ini bersifat open access yang didistribusikan di bawah syarat dan ketentuan Creative Commons Attribution (CC BY) license. (http://creativecommons.org/licenses/by/4.0/). 